\title{
Epidemiological and Serological Profile of Hepatitis B Virus in an Urban Area in Mali
}

\author{
Anselme Konaté1, H. Sow Wife Coulibaly¹, K. Doumbia Wife Samaké1, \\ Moussa Younoussou Dicko1*, R. Dembélé Wife Dakouo', A. Souckho Wife Kaya ${ }^{2}$, \\ Makan Ciré Tounkara1, Hamadoun Guindo1, Abdoulaye Maiga ${ }^{1}$, Mamadou Dembélé2, \\ Hamar Alassane Traoré ${ }^{2}$, Moussa Tiémoko Diarra ${ }^{1}$, Moussa Youssoufa Maiga ${ }^{{ }^{*}}$
}

\author{
${ }^{1}$ Hepato-Gastroenterology Department, CHU Gabriel Touré, Bamako, Mali \\ ${ }^{2}$ Department of Internal Medicine of the Point G Hospital, Bamako, Mali \\ Email: *dickmy9@yahoo.fr, *maigamoussay@yahoo.fr
}

How to cite this paper: Konaté, A., Coulibaly, H.S.W., Samaké, K.D.W., Dicko, M.Y., Dakouo, R.D.W., Kaya, A.S.W., Tounkara, M.C., Guindo, H., Maiga, A., Dembélé, M., Traoré, H.A., Diarra, M.T. and Maiga, M.Y. (2019) Epidemiological and Serological Profile of Hepatitis B Virus in an Urban Area in Mali. Open Journal of Gastroenterology, 9, 158-163. https://doi.org/10.4236/ojgas.2019.98018

Received: August 1, 2019

Accepted: August 16, 2019

Published: August 19, 2019

Copyright $\odot 2019$ by author(s) and Scientific Research Publishing Inc. This work is licensed under the Creative Commons Attribution International License (CC BY 4.0).

http://creativecommons.org/licenses/by/4.0/

\section{(c) (i) Open Access}

\begin{abstract}
The objective of our study was to evaluate hepatitis B virus (HBV) infection in an urban population. This longitudinal study was conducted in Bamako District and Kati Commune. After a preparatory phase, the persons who accepted the protocol were assessed for HBsAg. HBsAg carriers had blood collection for HBeAg assay, viral load assessment, genotyping, DNA mutation testing, and severity of hepatic fibrosis and necrosis. At the end of this study, 1475 persons were included, of which 195 had HBsAg positive confirmed, that is to say $13.97 \%$. The mean age of $\mathrm{HBsAg}$ positive patients was $35.11 \pm$ 11.12 years with a sex ratio of 2.68 . HBeAg was found in $8.9 \%$ of the patients tested for this antigen. The viral load was undetectable in $10.52 \%$ of patients and greater than $2000 \mathrm{IU} / \mathrm{mL}$ in $32.24 \%$ of cases. Fibrosis $\geq \mathrm{F} 2$ and necrosis $\geq$ A2 were found in respectively $19.72 \%$ and $6.80 \%$ of cases. Genotype E was found in 91.6 patients and an R249S mutation observed in $39.04 \%$ of cases. Conclusion: HBV infection has a serious impact on socio-economic development in Mali because it affects mainly the young male population, hence the need to organize preventive measures effectively.
\end{abstract}

\section{Keywords}

Hepatitis B Virus, Epidemiology, Serology, Bamako, Kati

\section{Introduction}

Hepatitis B virus (HBV) infection is an important global public health problem. In fact 240 million people, that is to say $5 \%$ of the world population, are chronic HBV carriers with a million of annual deaths [1] [2] [3] [4]. This mortality is 
commonly caused par cirrhosis and hepatocellular carcinoma (HCC). Unfortunately, there is now no treatment able to have the virus clearance. The best and most effective way to fight with the virus remains the universal vaccination of newborn children, which has shown in some asian countries.

Despite the cosmopolite character of this infection, it is more frequent in tropical areas specaily in sub-Saharan countries [1] [2].

In Mali, in an anterior study, at least one blood marker of HBV was found in 97.2\% of subjects tested for this virus [3]. In a recent study, the prevalence of HBs Antigen was $14.7 \%$ of the studied population [4]. On the other hand, Antigen $\mathrm{HBs}$ (HBsAg) was found in $15.5 \%$ of pregnant women and $43.2 \%$ of children born of the HBsAg positive women were also HBsAg positive after nine months of follow-up. In this age chronic carriage is very common [5] [6]. The involvement of hepatitis B virus in chronic liver disease has been demonstrated in our context by the presence of HBsAg in 55\% to $71 \%$ in cirrhosis and 55\% - $66.2 \%$ in hepatocellular carcinoma [7] [8] [9]. We undertook this study in some social groups of the district of Bamako and the city of Kati, in order to reevaluate the HBV infection epidemiological, after awareness campaigns and starting of vaccination against this HBV.

\section{Patients and Methods}

The longitudinal study, conducted in the district of Bamako and the city of Kati (Bamako border town), focused on any voluntary for HBV screening among medical students, health personnel, security agents and the general population. We included in the study was any person with HBV unknown status. According to the prevalence of this infection in the previous studies we selected in hazard 1500 persons.

A preparatory phase allowed the general population to be informed about the purpose and the course of the study.

After this step, blood samples were taken to be technically tested at the Biomérieux laboratory in Bamako and at the same time a simple questionnaire was administered about socio-demographic data and exposure to risk factors for transmission of the virus. HBsAg assay was performed on each sample taken by a rapid test of Roche laboratory: Best One Step HBsAg Test Disk. On the 1500 samples, 25 are used to validate the kits and finaly 1475 samples are defintively used for the study.

Samples revealed to be positive for HBsAg were then subjected to a confirmatory ELISA test of the Biomérieux laboratory: VIDAS HBs kit.

Confirmed carriers of $\mathrm{HBsAg}$ were reviewed for a second specimen for $\mathrm{HBe}$ antigen ( $\mathrm{HBeAg})$ at the Biomérieux laboratory in Bamako. Viral load, genotypes of the virus, DNA R249. Sutation and the evaluation of the hepatic impacted by Fibrotest/Actitest were performed at the BIOMNIS laboratory of Lyon (France).

Patients consent was obtained and the results were confidential. Non HBsAg positive people were informed and provided with the necessary information on the prevention of infection and the availability of doctors for any solicitation. 
For HBsAg positive patients a treatment was proposed in case of indication, otherwise a regular follow-up was recommended.

Data were collected on a survey card and analyzed in the Epi Info software (version 6.0). We used the $\mathrm{Chi}^{2}$ test to compare our results wich were considered significant for a probability $\mathrm{p}<0.05$.

\section{Results}

At the end of the study, 195 patients were $\mathrm{HbsAg}$ positive in a population of 1475 tested with a prevalence of $13.97 \%$.

The mean age of patients was $35.11 \pm 11.12$ years with extremes of 15 and 72 years and $81.6 \%$ of patients were under 45 years of age.

The sex ratio $(\mathrm{m} / \mathrm{f})$ was 2.68 .

No exposure to a major risk factor was found save for the status of health personnel.

HBeAg was present in $8.9 \%$ of patients tested for this antigen (8/90).

A viral load greater than $2000 \mathrm{IU} / \mathrm{mL}$ was found in $32.2 \%$ of patients (Table 1).

Among eight $\mathrm{HBeAg}$ positive patients, seven had a viral load greater than $2000 \mathrm{IU} / \mathrm{mL}(\mathrm{p}=0.00045)$.

Moderate to severe fibrosis $(\mathrm{F} \geq 2)$ was found in $19.7 \%$ of patients and necrosis was significant $(A \geq 2)$ in $6.8 \%$ of patients (Table 2). Fibrosis and necrosis were significantly associated $(\mathrm{p}=0.0006)$. A viral load greater than $2000 \mathrm{IU} / \mathrm{mL}$ was associated with moderate to severe fibrosis in $24.4 \%$ of cases (Table 3 ). There was no relationship between viral load and degree of liver fibrosis (Spearman correlation p: 0.33).

Table 1. Patient distribution according to HBV viral load.

\begin{tabular}{ccc}
\hline Viral load $(\mathrm{IU} / \mathrm{mL})$ & Number & Percentage \% \\
\hline Undetectable & 16 & 10.6 \\
$\leq 2000$ & 87 & 5.2 \\
$>2000$ & 49 & 32.2 \\
Total & 152 & 100 \\
\hline
\end{tabular}

Table 2. Scores of fibrosis and activity at actitest.

\begin{tabular}{cccc}
\hline Fibrotest $^{\circledR}$ & Number (\%) & Actitest & Number (\%) \\
\hline F0 & $69(46.9)$ & A0 & $84(57.1)$ \\
F0 - F1 & $20(13.6)$ & A0 - A1 & $38(25.9)$ \\
F1 & $6(4.1)$ & A1 & $10(6.8)$ \\
F1 - F2 & $23(15.7)$ & A1 - A2 & $5(3.4)$ \\
F2 & $10(6.8)$ & A2 & $5(3.4)$ \\
F3 & $11(7.5)$ & A3 & $5(3.4)$ \\
F4 & $8(5.4)$ & & \\
Total & $\mathbf{1 4 7 ( 1 0 0 )}$ & Total & $\mathbf{1 4 7 ( 1 0 0 )}$ \\
\hline
\end{tabular}


Table 3. Patient distribution according to fibrotest and viral load.

\begin{tabular}{cccc}
\hline $\begin{array}{c}\text { Viral load (IU/mL) } \\
\text { Fibrotest }^{\circledR}\end{array}$ & $\begin{array}{c}\mathbf{5 2 0 0 0} \\
\mathrm{n}(\%)\end{array}$ & $\begin{array}{c}>\mathbf{2 0 0 0} \\
\mathbf{n}(\%)\end{array}$ & Total \\
\hline F0 & $43(45.7 \%)$ & $20(44.4 \%)$ & 63 \\
F0 - F1 & $14(14.9 \%)$ & $5(11.1 \%)$ & 19 \\
F1 & $3(3.2 \%)$ & $3(6.6 \%)$ & 6 \\
F1 + F2 & $17(18.1 \%)$ & $6(13.3 \%)$ & 23 \\
F2 & $4(4.3 \%)$ & $6(13.3 \%)$ & 10 \\
F3 & $6(6.4 \%)$ & $4(8.9 \%)$ & 10 \\
F4 & $7(7.4 \%)$ & $1(2.2 \%)$ & 8 \\
Total & 94 & 45 & 139
\end{tabular}

Genotype performed among 90 patients: genotype E was found in 82/90 patients $(91.1 \%)$. One genotype $\mathrm{E}$ was associated with a genotype $\mathrm{D}$ in $5 / 90$ patients (5.6\%).

DNA R249S mutation was found in 41/105 patients (39.05\%).

\section{Discussion}

This longitudinal study reported the epidemiological and serological profile of the hepatitis B virus in the Bamako District (Gabriel Touré and point "G" Teaching Hospitals, security agents, students) and in the city of Kati (Kati Hospital).

The main limit of this study is that some people did not come for the confirmation test it is why the tables are not the same total. The exams were done on best conditions. The course of the study respected all ethical aspects.

HbsAg prevalence at $13.97 \%$ in this study confirms the data from previous studies about this virus in Mali ranging our country into the highly endemic area for this infection [1] [2] [3] [4]. This prevalence is considerable because it is estimated that $15 \%$ to $40 \%$ of carriers of the hepatitis B virus will have a complication related to this infection during their lifetime [10]. It is comparable to those of Diallo [11], Guindo [12] and Tangara [13] who found respectively rates of $12.1 \%, 14.9 \%$, and $15.72 \%$.

The absence of any exposure to the blood in this youth population suggests horizontal or vertical contamination in childhood. Newborn vaccination at birth had thus an interest because of the frequent passage to chronicity in case of contamination at this age.

The particularity of this infection is its high frequency in man $(72.8 \%$ of the sample) and the young subject accounted for $81.6 \%$. This high representativeness of young people has already been reported by previous studies in both rural and urban areas [4] [14]. The socio-economic impact of this infection is thus demonstrated because it affects the most productive social group.

HBe antigen was found in $8.9 \%$ of the subjects tested for this antigen and a 
viremia greater than $2000 \mathrm{IU} / \mathrm{mL}$ was reported in $32.2 \%$ of 152 people who had the viral load assay. Despite these relatively low levels of replication markers, hepatitis B virus infection should always be a concern because of the potentially daunting complications however the status of the infection.

Moderate to severe fibrosis and significant necrosis were observed in 19.7\% and $6.8 \%$ of cases, respectively. These states predispose to complications. In our region, several studies have reported the association of hepatitis B virus with cirrhosis [8] [9] [15] [16]. The carcinogenic role of the hepatitis B virus is proven in Africa, as several studies have reported its association with HCC [10] [15] [17].

The strong representation of genotype $\mathrm{E}$ is consistent with literature data on genotype E predominant in West Africa. The frequency of the DNA mutation of R249S in our context of high theoretical aflatoxin consumption could explain the important prevalence of HCC.

\section{Conclusion}

Hepatitis B virus infection is a real public health problem in Mali. It has a serious impact on socio-economic development, mainly affecting the young male population. Preventive measures against this virus, in particular, a routine birth vaccination policy, are needed to reduce its prevalence and thus the incidence of cirrhosis and HCC in our context.

\section{Conflicts of Interest}

The authors declare no conflicts of interest regarding the publication of this paper.

\section{References}

[1] European Association for the Study of Liver (2017) Clinical Practice Guidelines on the Management of Hepatitis B Virus Infection. Journal of Hepatology, 67, 370-398.

[2] World Health Organization (2002) WHO/CDS/CSR/LYO/2002.2.

[3] Sidibe, S. (1981) Serological Markers of Hepatitis B in Mali. Thesis, Med, Bamako, $30 \mathrm{SS}$.

[4] Bougoudogo, F., Diarra, S., Traore, S. and Niangaly, A. (2001) Report on the Prevalence of Markers of Hepatitis B Virus Infection in Mali. 1-35.

[5] Sidibe, S., Sacko, Y. and Traore, I. (2001) Prevalence of Serologic Markers of Hepatitis B Virus in Pregnant Women in Bamako District, Mali. Bulletin de la Société de Pathologie Exotique, 94, 339-341.

[6] Sidibe, S., Sacko, M., Sangho, H., Sacko, B., Doumbo, O. and Traore, I. (2000) Epidemiology of Mother-to-Child Transmission of Hepatitis B Virus in the District of Bamako. The Euro Biologist, 34, 93-96.

[7] Dembele, M., Maiga, I., Minta, D., Konate, A., Diarra, M., Sangare, D., et al. (2004) Study of HBsAg and Antibodies against Hepatitis C Virus in Hospital Services in Bamako-Mali. Bulletin de la Société de Pathologie Exotique, 97, 161-164.

[8] Maïga, M.Y., Dembele, M., Diallo, F., Traore, H., Traore, A. and Guindo, A. (2002) Diagnostic Value of High Digestive Endoscopy during Cirrhosis. Acta Endoscopica, 32, 211-218. https://doi.org/10.1007/BF03016657 
[9] Diarra, M., Konate, A., Dembele, M., Kone, B., Wandji, M.J., Maiga, M.Y., et al. (2006) Hepatocellular Carcinoma: Epidemiological and Evolutionary Aspects. Black African Medicine, 53, 23-28.

[10] Zoulim, F., Kay, A., Merle, P. and Trepo, C. (2006) Virology of Hepatitis B. EMC (Elsevier SAS, Paris), Hepatology, 7-015-B30.

[11] Diallo, A.H. (2006) Seroprevalences of Co-Infection by Hepatitis B and C Viruses in Blood Donors in Bamako. Thesis, Pharm, Bamako, 55.

[12] Guindo, O. (2003) HIV and HBV Infection in Blood Donors at CNTS Bamako. Thesis, Pharm, Bamako, 46.

[13] Tangara, O. (2004) Co-Infection of Hepatitis B and Hepatitis C in Blood Donors at the National Center for Blood Transfusion. Thesis, Pharm, Bamako, 61.

[14] Dembele, N. (2006) Seroprevalence of Hepatitis B Infection among School Aged 15-25 in Bamako, Koulikoro, Sikasso. Thesis, Pharm, Bamako, 41.

[15] Chattin, J.L. (1994) Epidemiology of Hepatitis B Virus Infection in Tunisia. Maghreb Medicine, 278, 15-18.

[16] Perret, J.L., Kombila, M.J.B., Delaporte, D.L.F., Boguikouma, J., Matton, T., et al. (2002) HBsAg and Anti-Hepatitis C Virus Antibodies in Complicated Liver Diseases in Gabon: A Case-Control Study. Gastroentérologie Clinique et Biologique, 26, 131-135.

[17] Lehman, E. and Wilson, M.L. (2009) Epidemiology of Hepatitis Virus among Hepatocellular Carcinoma Cases and Healthy People in Egypt: A Systematic Review and Meta-Analysis. International Journal of Cancer, 124, 690-967.

https://doi.org/10.1002/ijc.23937

\section{Questionnary}

\section{$\underline{\text { Patient identity }}$}

Surname: Name:

Gender:

Age:

Profession:

Adresse:

Numéro de Tel:

Antecedents

Transfusion

Jaundice

Tattoo

Other expositions Yes

No

If yes specify:

Virus markers: $\mathrm{HBs} A g \quad \mathrm{HBe} A g \quad$ Viral load

Genotype:

ADN mutation

Aminotransferase;

ALAT:

ASAT:

Fibrosis and necrosis staging 